\title{
Editorial
}

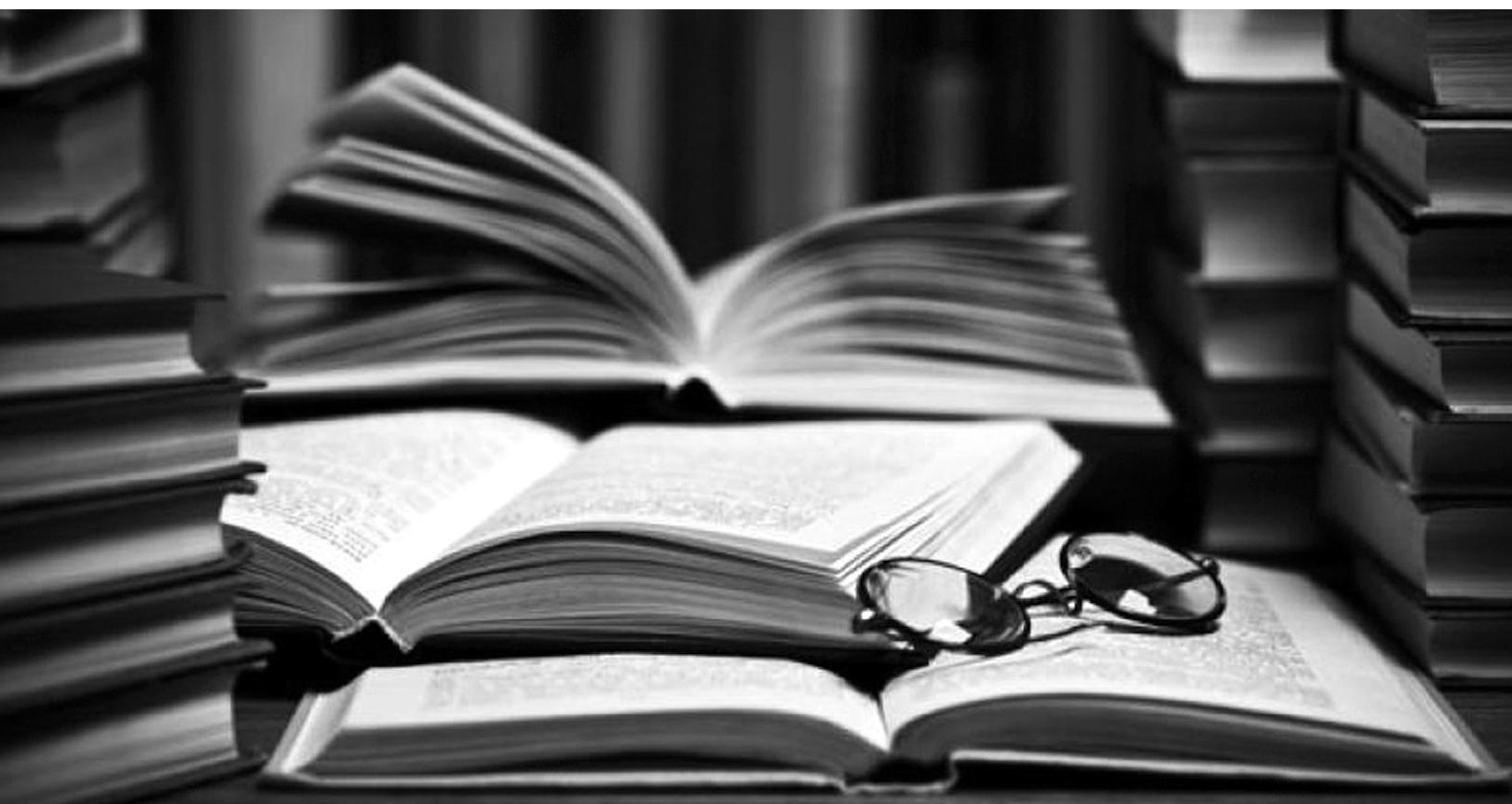





\section{¿Como debe juzgar el impartidor de justicia?}

Pensar en el significado del derecho en una sociedad que se estructura en base a un Estado de Derecho, indudablemente es pensar no solo en el momento de creación del derecho como protección de bienes jurídicos sino también en el momento -quizá el más importante para los ciudadanos- de la aplicación de la justicia.

La configuración de los procesos civiles, familiares, laborales, penales, administrativos, agrarios, y de cualquier proceso en general tiene que ver con la declaración del derecho frente a la Litis, pero ese reconocimiento del derecho trasciende a las partes y toma sentido social cuando impacta directamente temas tan relevantes como la legitimación del Estado Social y Democrático de Derecho; el respeto por los Derechos Humanos en el bloque constitucional y convencional, según los estándares internacionales y en definitiva, la credibilidad social que puede llegar a tener la justicia.

Por todo ello, se busca que la aplicación del derecho mediante la resolución judicial establezca el vínculo natural de aplicación de justicia, y lamentablemente no en pocos casos queda ésta rezagada, ya lo decía Carnelutti: El Juicio es la mayor dificultad que el hombre encuentra en su camino. Nuestra tragedia está en que no podemos actúa sin juzgar, pero no sabemos juzgar.

Lo primero que vale la pena señalar es que dentro de los requisitos de la sentencia existen los elementos formales -la forma de la sentencia- pero también los sustanciales: congruencia, motivación y exhaustividad. La primera se refiere a la identidad entre lo resuelto y lo controvertido; la segunda a la exigencia de precisar los hechos en que se funde la decisión con base en las pruebas practicadas y su valoración y la tercera en resolver sobre todo lo pedido por las partes.

La teoría reconoce que la motivación es un tema altamente relevante y requiere de un estudio más pormenorizado, como dice Taruffo: a través de la motivación el juez demuestra la solidez, la legitimidad y la racionalidad de las decisiones. Se 
distinguen en este sentido dos categorías de razonamiento en la valoración de la prueba: El razonamiento decisorio, en donde se valora la prueba y se formula la decisión sobre los hechos; y el razonamiento justificativo en donde el juez motiva la decisión.

En tal sentido, existen tres sistemas de valoración de la prueba: a) Íntima convicción, en la cual no hay reglas pre establecidas y sólo se requiere que el juzgador informe sobre la conclusión fáctica a la cual ha llegado, sin explicar como lo ha hecho; b) Prueba legal, en la cual se regula las condiciones que se deben reunir para llegar a la convicción, c) Sana crítica, en la que hay ausencia de reglas abstractas de valoración probatoria, pero exige la fundamentación de la decisión con la explicitación de los motivos que la fundan y cómo fueron valorados.

El estándar en el proceso penal es diferente al estándar en el proceso civil, en éste último se utiliza el estándar de probabilidad prevalente en donde se da por probada la versión de los hechos que aparece como más probable a la luz de las pruebas obtenidas y en cambio, en el proceso penal el estándar de la prueba más allá de toda duda razonable, se basa en que solo en el caso de que la prueba haya ofrecido certeza sobre los hechos podría ser condenado el acusado.

En definitiva, la sentencia en el proceso penal debe observar en todo momento los principios de presunción de inocencia, In dubio pro reo y estándar de la prueba más allá de toda duda razonable, solo de esta manera el juzgador estará impartiendo justicia.

Invierno 2020

Dra. Silvia Patricia López González Directora - Editora 